Hill and Upland Livestock Production

Occasional Publication No. 10-British Society of Animal Production 1985

edited by T. J. Maxwell and R. G. Gunn

\title{
THE EFFECT OF CROP STRUCTURE IN RAPE (BRASSICA NAPUS) ON FORAGE INTAKE AND PERFORMANCE BY BLACKFACE LAMBS
}

\author{
R. H. ARMSTRONG and M. M. BEATTIE
}

Hill Farming Research Organisation, Bush Estate, Penicuik, Midlothian EH26 OPY

$\mathbf{T}$

The performance of unsupplemented weaned hill lambs on Brassica crops is only moderate, even when a plentiful supply of forage is available. Rape (Brassica napus) is commonly used and there is evidence that it is superior to some other Brassica crops (e.g. Fitzgerald and Black, 1984).

Although these slow rates of live-weight gain are not necessarily economically disadvantageous, even the better growth rates are achieved at the expense of low levels of crop utilisation (Patterson, Dickson and Berlyn, 1977). The limited available evidence suggests that poor animal performance is due to low levels of forage intake (Young, Austin, Orr, Newton and Taylor, 1982). Evidence on the factors responsible for low intake is not clear, although it has been suggested that this is due to intrinsic factors such as low dry matter content or the presence of antimetabolites such as S-meth-L-cysteine sulphoxide or glucosinolates in the crop (Barry, Manley and Millar, 1982).

Preliminary pen-feeding and grazing studies (Hill Farming Research Organisation, Biennial Report, 19823) showed that, in spite of very high digestibility, the intake of rape leaf and stem was low when offered to weaned Blackface lambs or to adults. Subsequent studies using 'Lair' giant rape harvested and fed indoors showed that there were significant differences between the organic matter digestibility of lamina, petiole, upper stem and lower stem; values being $0.84,0.89,0.86$ and 0.77 , respectively. There were also significant differences in organic matter intake; values ( $g /$ day) for lamina, petiole, upper stem and lower stem, respectively, being 460, 694, 650 and 524. There was no clear evidence of the possible effect of digestibility or contents of water, fibre or antimetabolites in forage on intake, although low lamina intake may be related to high thiocyanate levels.

A grazing experiment was conducted concurrently so that lambs grazed either 'leaf' (lamina plus petiole) or 'stem' on a leader:follower system at 33 lambs/ha. The live-weight gain of lambs grazing leaf was $169 \mathrm{~g} /$ day while lambs on stem gained 112 g/day and these values broadly reflected the levels of digested organic matter intake achieved. Intake on both grazing treatments was higher than indoors, especially for leaf.

There may be scope for controlling lamb performance and levels of crop utilisation in forage crops by varying crop morphology; further investigations are required into these effects for both plant breeding and management objectives.

\section{REFERENCES}

Barry, T. N., MANLey, T. R. and Millar, K. R. 1982. Nutritional evaluation of kale (Brassica oleracea) diets. 4. Responses to supplementation with synthetic S-methyl-L-cysteine sulphoxide. J. agric. Sci., Camb. 99: 1-12.

Frtzgerald, S. and Black, W. J. M. 1984. Finishing store lambs on green forage crops. 1. A comparison of rape, kale and fodder radish as sources of feed for finishing store lambs in autumn. Ir. J. agric. Res. 23: 127-136.

Patterson, W. G. W., Dickson, I. A. and Berlyn, P. 1977. Evaluation of forage crops via fattening lambs. In Brassica Fodder Crops (ed. J. F. D. Greenhalgh, I. McNaughton and R. F. Thow). Scottish Agricultural Development Council and Scottish Plant Breeding Station.

Young, N. E., Austin, A. R., ORR, R. J., Newton, J. E. and TAYlor, R. J. 1982. A comparison of a hybrid stubble turnip (cv Appin) with other cruciferous catch crops for lamb fattening. 2. Animal performance and toxicological evaluation. Grass and Forage Sci. 37: 39-46. 